\title{
Knowledge of Adolescents Regarding Health Implications of Body Piercing
}

\author{
Meethu Raju', Maria Elizabeth², Mary Thomas ${ }^{3}$, Meenu Francis ${ }^{4}$, \\ Mayolla DSouza ${ }^{5}$, Nijisha Sharli ${ }^{6}$ \\ ${ }^{1-5} 4$ th Year B.Sc Nursing Student, Father Muller College of Nursing, Mangaluru-575002, Karnataka, India \\ ${ }^{6}$ Lecturer, Obstetrics and Gynecological Nursing Department, Father Muller College of Nursing, \\ Mangaluru-575002, Karnataka, India \\ Corresponding Author: Nijisha Sharli
}

\begin{abstract}
The period of puberty to legal adulthood falls under the age group of 17-19, and the Transitional stage of physical and psychological development falls under this age. In a modern scenario the adolescents are aware of the different kind of piercing since it has been increasing popularity around the world. Piercing has a high potential for infectious complications such as pain, edema, prolonged bleeding, cyst, scar, or Keloid.

Objectives: To assess the knowledge level of adolescents regarding health implication of body piercing and to find the association between knowledge score and demographic variables.

Materials and Methods: A descriptive research design was adopted in this study. The sample consists of 92 adolescents. The study was conducted in Father Muller Medical College, Mangaluru. A Knowledge Questionnaire was used to collect the data regarding knowledge on health implication of body piercing.

Result: The findings revealed that majority 52 (56.5\%) of the adolescents had poor knowledge and 37 (40.2\%) of them had an average knowledge on health implication of body piercing. Very few 3(3.3\%) had good knowledge on health implication of body piercing. There exists no significant association of knowledge score with the selected demographic variables.

Interpretation and Conclusion: The study concluded that majority of the adolescents have a general lack of knowledge about body piercing and its adverse effects; this causes an increased risk of adverse effects following body piercing. A health teaching on the health implications of body piercing will be very helpful for the young people to acquire knowledge and to practice accordingly.
\end{abstract}

Keywords: Body piercing, Adolescents, Health Implication, Knowledge.

\section{INTRODUCTION}

Body piercing, a form of body modification, is the practice of puncturing or cutting a part of the human body creating an opening in which jewellery may be worn or where an implant could be inserted. The word piercing can refer to the act or practice of body piercing, or to an opening in the body created by act or practice ${ }^{1}$.

People pierce for varying reasons such as religious or spiritual reasons, selfexpression, aesthetic value, sexual pleasure and conform to their culture or rebel against it. Ear piercing and nose piercing have seen particularly widespread and are well represented in historical records and among grave goods. The trend of body piercing at the sites other than earlobes has grown in popularity in the past decade. The tongue, lips, nose, eyebrows, nipples, navel and genitals may be pierced ${ }^{1}$

Recently, piercing and tattooing have gained increasing popularity worldwide. Although the literature differs on the basis of area and population studied, it indicates that body art is increasingly 
accepted by all social classes and age groups, but especially by youths. Body piercing poses a risk for serious disease, because it invades subcutaneous areas. Piercing has a high potential for infectious complications. Many of the adolescents are unaware of the complications related to body piercing such as pain, edema, prolonged bleeding, cyst, scar, or Keloid ${ }^{2}$.

Galle $\mathrm{F}$, et al investigated perceptions of knowledge about health risks of body art practices among students at high schools and universities in the province of Naples. They conducted study on 9322 adolescents, $31.3 \%$ were pierced and 11.3 were tattooed. Among 3610 undergraduate $33 \%$ were pierced and $24.5 \%$ were tattooed. He found that a higher number of females were pierced in both samples, but there were no gender differences among tattooed students. Among the high school students most of them knew about the infectious risk and few students knows about non infectious diseases, but a very few knows about risk of viral disease transmission and allergic risk. $73 \%$ of high school students and 33.55 of university students had 6 body art done at unauthorized facilities and approximately $7 \%$ of both samples reported complications from their purchased body $\operatorname{art}^{3}$.

A study was conducted among youths regarding awareness about transmission of hepatitis $\mathrm{C}$ virus infection through tattooing and body piercing by Tohme Atlanta. The study summarizes the findings of assessed risks of HCV infection among those who reported having a body or ear piercing only 5 of 23 studies reported an increased risk of $\mathrm{HCV}$ infection among persons with piercings ${ }^{6}$.

The main aim of the study includes

1. To assess the knowledge level of adolescents regarding health implication of body piercing.

2. To find the association between knowledge score of adolescents regarding health implications of body piercing and selected demographic variables.

\section{MATERILAS AND METHODS}

The present study was descriptive in nature. The study was carried out on 92 adolescent B.P.T student of Father Muller Medical College Mangaluru. The sampling method used was non- convenient sampling technique. The study was approved by the Institutional Review Committee. Permission was obtained from the college authorities and informed consent was obtained from the participants who fulfilled the inclusion criteria. The inclusion criteria to participate in the study were Student adolescents who are between the ages of 17-19 years who were present during the study period. A structured knowledge questionnaire was prepared by the investigators after a thorough review of literature, and it was validated by eight experts. The structured knowledge questionnaire included questions on knowledge regarding health implication of body piercing. Each question carried one mark for correct response and zero for incorrect one. Maximum score was 20 and minimum was 0 . Anonymity and confidentiality were maintained

\section{STATISTICAL ANALYSIS}

- Demographic profile in terms of frequency and percentage.

- Association of demographic variables with knowledge score on antenatal women was done using Chi-square test.

\section{RESULT \\ SECTION I: DEMOGRAPHIC VARIABLES}

This section deals with the description of sample characteristics of subjects which is explained in frequency and percentage.

From the table 1, it can be interpreted that majority of the students were of the age group of 19 years that is 38 (41.3\%), the majority of the 36 students were female that is $82.6 \%$ and most of the students were Christians that is 72 (78.3\%) and 69 (75\%) of them belongs to urban areas. Most of their fathers were selfemployed and mothers were unemployed 
that is $61 \quad(66.3 \%)$ and $50 \quad(54.3 \%)$ respectively. About 45 (48.9\%) of students having the income of 10001-500000 per month and $82(89.1 \%)$ of them have siblings. Around 89 (96.7\%) has previous knowledge regarding body piercing.

Table 1: Frequency and percentage distribution of Adolescents according to baseline variables, $\mathrm{N}=92$

\begin{tabular}{|c|c|c|c|}
\hline $\begin{array}{l}\text { Sl. } \\
\text { No }\end{array}$ & Variables & $\begin{array}{l}\text { Frequency } \\
\text { (f) }\end{array}$ & $\begin{array}{l}\text { Percentage } \\
\text { (\%) }\end{array}$ \\
\hline 1 & $\begin{array}{l}\text { Age in years: } \\
17 \\
18 \\
19\end{array}$ & $\begin{array}{l}17 \\
37 \\
38\end{array}$ & $\begin{array}{l}18.5 \\
40.2 \\
41.3\end{array}$ \\
\hline 2 & $\begin{array}{l}\text { Gender: } \\
\text { Male } \\
\text { Female }\end{array}$ & $\begin{array}{l}16 \\
76\end{array}$ & $\begin{array}{l}17.4 \\
82.6\end{array}$ \\
\hline 3 & $\begin{array}{l}\text { Religion: } \\
\text { Hindu } \\
\text { Christian } \\
\text { Muslim }\end{array}$ & $\begin{array}{l}14 \\
72 \\
6\end{array}$ & $\begin{array}{l}15.2 \\
78.3 \\
6.5\end{array}$ \\
\hline 4 & $\begin{array}{l}\text { Residence: } \\
\text { Rural } \\
\text { Urban } \\
\end{array}$ & $\begin{array}{l}23 \\
69 \\
\end{array}$ & $\begin{array}{l}25.0 \\
75.0\end{array}$ \\
\hline 5 & $\begin{array}{l}\text { Fathers Occupation: } \\
\text { Government } \\
\text { Employed } \\
\text { Self Employed } \\
\text { Unemployed }\end{array}$ & $\begin{array}{l}21 \\
61 \\
10\end{array}$ & $\begin{array}{l}22.8 \\
66.3 \\
10.9\end{array}$ \\
\hline 6 & $\begin{array}{l}\text { Mothers Occupation: } \\
\text { Government } \\
\text { Employed } \\
\text { Self Employed } \\
\text { Unemployed } \\
\end{array}$ & $\begin{array}{l}22 \\
20 \\
50\end{array}$ & $\begin{array}{l}23.9 \\
21.7 \\
54.3\end{array}$ \\
\hline 7 & $\begin{array}{l}\text { Income per month(in } \\
\text { rupee) } \\
\leq 10000 \\
10001-50000 \\
50001-100000 \\
\geq 100000\end{array}$ & $\begin{array}{l}8 \\
45 \\
26 \\
13 \\
\end{array}$ & $\begin{array}{l}8.7 \\
48.9 \\
28.3 \\
14.1 \\
\end{array}$ \\
\hline 8 & $\begin{array}{l}\text { Sibling } \\
\text { Yes } \\
\text { No }\end{array}$ & $\begin{array}{l}82 \\
10 \\
\end{array}$ & $\begin{array}{l}89.1 \\
10.9 \\
\end{array}$ \\
\hline 9 & $\begin{array}{l}\text { Previous Knowledge } \\
\text { Yes } \\
\text { No }\end{array}$ & $\begin{array}{l}89 \\
3\end{array}$ & $\begin{array}{l}96.7 \\
3.3\end{array}$ \\
\hline
\end{tabular}

\section{SECTION II: ASSESSMENT OF \\ KNOWLEDGE LEVEL OF ADOLESCENTS REGARDING HELATH IMPLICATIONS OF BODY PIERCING}

Table 2: Distribution of knowledge score based on pre-test and post- test, $\mathrm{N}=92$

\begin{tabular}{|l|l|l|l|l|}
\hline $\begin{array}{l}\text { Sl. } \\
\text { No. }\end{array}$ & Grading & $\begin{array}{l}\text { Range of } \\
\text { score }\end{array}$ & Frequency & Percentage \\
\hline 1 & Good & $16-20$ & 3 & 3.3 \\
\hline 2 & Average & $11-15$ & 37 & 40.2 \\
\hline 3 & Poor & $\leq 10$ & 52 & 56.5 \\
\hline \multicolumn{4}{|c|}{ Maximum Score $=20$} \\
\hline
\end{tabular}

The data presented in Table 2 shows that the majority of the adolescents having poor knowledge i.e.; 52 (56.5\%) and only 3 (3.3\%) are having good knowledge while about 37(40.2\%) has average knowledge about the health implications of body piercing.

Table 3: Domain wise mean, standard deviation and mean percentage of knowledge score, $\mathrm{N}=92$

\begin{tabular}{|l|l|l|l|}
\hline $\begin{array}{l}\text { Minimum } \\
\text { obtained } \\
\text { score }\end{array}$ & $\begin{array}{l}\text { Maximum } \\
\text { obtained } \\
\text { score }\end{array}$ & $\begin{array}{l}\text { Mean } \pm \text { Standard } \\
\text { Deviation }\end{array}$ & $\begin{array}{l}\text { Mean } \\
\text { percentage }\end{array}$ \\
\hline 3 & 17 & $10.0109 \pm 2.92956$ & 50.05 \\
\hline
\end{tabular}

The data in the Table 3 shows that among 92 adolescents the minimum score obtained is 3 and maximum score obtained is 17 out of the 20 total knowledge questions. The mean percentage of the knowledge score is $50.05 \%$.

\section{SECTION III: ASSOCIATION BETWEEN THE KNOWLEDGE OF ADOLESCENTS REGARDING HELATH IMPLICATIONS OF BODY PIERCING WITH SELECTED DEMOGRAPHIC VARIABLES}

\begin{tabular}{|c|c|c|c|c|c|c|}
\hline \multirow[t]{2}{*}{ Sl. No. } & \multirow[t]{2}{*}{ Demographic proforma } & \multicolumn{3}{|c|}{ Knowledge Score } & \multirow[t]{2}{*}{ Chi-Square } & \multirow[t]{2}{*}{ p-value } \\
\hline & & Good & Average & Poor & & \\
\hline 1 & $\begin{array}{l}\text { Age in years } \\
17 \\
18 \\
19 \\
\end{array}$ & $\begin{array}{l}0 \\
2 \\
1 \\
\end{array}$ & $\begin{array}{l}8 \\
12 \\
17 \\
\end{array}$ & $\begin{array}{l}9 \\
23 \\
20 \\
\end{array}$ & 2.419 & 0.659 \\
\hline 2 & $\begin{array}{l}\text { Gender } \\
\text { Male } \\
\text { Female } \\
\end{array}$ & $\begin{array}{l}0 \\
3 \\
\end{array}$ & $\begin{array}{l}14 \\
33 \\
\end{array}$ & $\begin{array}{l}12 \\
40 \\
\end{array}$ & 2.917 & 0.233 \\
\hline 3 & $\begin{array}{l}\text { Religion } \\
\text { Hindu } \\
\text { Christian } \\
\text { Muslim } \\
\end{array}$ & $\begin{array}{l}1 \\
2 \\
0\end{array}$ & $\begin{array}{l}6 \\
28 \\
3 \\
\end{array}$ & $\begin{array}{l}7 \\
42 \\
3 \\
\end{array}$ & 1.285 & 0.864 \\
\hline 4 & $\begin{array}{l}\text { Residence } \\
\text { Rural } \\
\text { Urban }\end{array}$ & $\begin{array}{l}0 \\
3 \\
\end{array}$ & $\begin{array}{l}8 \\
29 \\
\end{array}$ & $\begin{array}{l}15 \\
37\end{array}$ & 1.635 & 0.441 \\
\hline
\end{tabular}




\begin{tabular}{|c|c|c|c|c|c|c|}
\hline \multicolumn{7}{|c|}{ Table 4 Continued... } \\
\hline 5 & $\begin{array}{l}\text { Fathers Occupation } \\
\text { Government Employed } \\
\text { Self Employed } \\
\text { Unemployed }\end{array}$ & $\begin{array}{l}1 \\
2 \\
0\end{array}$ & $\begin{array}{l}5 \\
27 \\
5 \\
\end{array}$ & $\begin{array}{l}15 \\
32 \\
5\end{array}$ & 3.442 & 0.487 \\
\hline 6 & $\begin{array}{l}\text { Mothers Occupation } \\
\text { Government Employed } \\
\text { Self Employed } \\
\text { Unemployed }\end{array}$ & $\begin{array}{l}1 \\
0 \\
2 \\
\end{array}$ & $\begin{array}{l}8 \\
9 \\
20 \\
\end{array}$ & $\begin{array}{l}13 \\
11 \\
28 \\
\end{array}$ & 1.079 & 0.898 \\
\hline 7 & $\begin{array}{l}\text { Income per month(in rupee) } \\
<10000 \\
10001-50000 \\
50001-100000 \\
>100001\end{array}$ & $\begin{array}{l}0 \\
1 \\
1 \\
1\end{array}$ & $\begin{array}{l}2 \\
20 \\
10 \\
5\end{array}$ & $\begin{array}{l}6 \\
24 \\
15 \\
7 \\
\end{array}$ & 2.497 & 0.869 \\
\hline 8 & $\begin{array}{l}\text { Siblings } \\
\text { Yes } \\
\text { No }\end{array}$ & $\begin{array}{l}3 \\
0 \\
\end{array}$ & $\begin{array}{l}34 \\
3 \\
\end{array}$ & $\begin{array}{l}45 \\
7 \\
\end{array}$ & 1.018 & 0.601 \\
\hline 9 & $\begin{array}{l}\text { Previous knowledge } \\
\text { Yes } \\
\text { No }\end{array}$ & $\begin{array}{l}3 \\
0\end{array}$ & $\begin{array}{l}34 \\
3\end{array}$ & $\begin{array}{l}52 \\
0 \\
\end{array}$ & 4.610 & 0.100 \\
\hline
\end{tabular}

The data presented in Table 4, reveals that the $\mathrm{p}$ value computed between knowledge and age (0.659), gender (0.233), religion (0.864), Residence (0.534), Fathers Occupation (0.487), Mothers Occupation (0.898), Income per month (0.869), Siblings (0.601), Previous knowledge (0.100) and all these are $<0.05$ level of significance. Hence, there is no association with knowledge score and demographical variables. Hence, the null hypothesis is accepted.

\section{DISCUSSION}

The present study shows that majority of the students were of the age group of 19 years that is 38 (41.3\%), the majority of the 36 students were female that is $82.6 \%$ and most of the students were Christians that is 72 (78.3\%) and 69 (75\%) of them belongs to urban areas. Most of their fathers were self-employed and mothers were unemployed that is 61 (66.3\%) and 50 (54.3\%) respectively. About 45 (48.9\%) of students having the income of $10001-500000$ per month and $82(89.1 \%)$ of them have siblings. Around 89 (96.7\%) has previous knowledge regarding body piercing.

In the present study, the data suggests that majority 52 (56.5\%) students possessed poor knowledge, 37 (42.7\%) of them had average knowledge and only 3 (3.3\%) of students are having good knowledge.
In the study $\mathrm{p}$ value computed between knowledge score and demographic variable like age $(\mathrm{p}=0.659)$, gender $(\mathrm{p}=0.233)$, religion $37(\mathrm{p}=0.864)$ residence ( $\mathrm{p}=0.441$ ), fathers and mothers' occupation $(\mathrm{P}=0.487$ and $\mathrm{p}=0.898)$ Income $(\mathrm{p}=0.869)$ siblings (0.601), Previous knowledge $(0.100)$ and all these are $<0.05$ level of significance

A descriptive research design was used to find out the knowledge regarding tattooing and body piercing. A total of 50 respondents having both the body tattooed and pierced present in Thamel-29, Kathmandu were selected using nonprobability purposive sampling technique. A semi structured interview schedule was used to collect the data and was analyzed by using SPSS. The findings revealed that the respondents were adolescents and young adults among whom the majority (48\%) had high knowledge, least (18\%) had average knowledge and one third (34\%) had low knowledge regarding Tattooing and Body Piercing. Statistically, there was significant association between the occupation and participation of the respondents in programs related to tattooing and body piercing with their knowledge score. ${ }^{5}$

Greif J, et al conducted a study of 766 tattooed and -or body pierced college students in 18 universities across the United States and one in Australia to discover the demographic characteristics, motivational factors and health concerns. They found that 
the traditional college time of 18 to 22 years of age was when they obtained their tattoo and body piercing. More frequent health problem and impulsive decision making were noted for those with body piercing when compared to those tattooed. Three cases of Hepatitis were reported ${ }^{4}$.

\section{CONCLUSION}

The study concluded that majority of the adolescents have a general lack of knowledge about body piercing and its adverse effects; this causes an increased risk of adverse effects following body piercing. So, a health teaching on the health implications of body piercing will be very helpful for the young people to acquire knowledge and to practice accordingly.

Acknowledgement: None

\section{Conflict of Interest: None}

\section{Source of Funding: None}

\section{Ethical Approval: Approved}

\section{REFERENCES}

1. Body piercing information. Available from: http://en.m.wikipedia.org/wiki/body_piercin $\mathrm{g}$

2. Donna I. Meltzer. Complications of Body Piercing. American Family Physician.
November 15 ;( November 15, 2005). Available from: https://www.aafp.org/afp/2005/1115/p2029. html

3. Gallè F, Mancusi C, Onofrio VD, Visciano A, Alfano V, Mastronuzzi R, et al. Awareness of health risks related to body art practices among youth in Naples, Italy: a descriptive convenience sample study. BMC Public Health. 2011 Dec;11 (1):625. Available from: https://pubmed.ncbi.nlm.nih.gov/21819558/

4. Greif J, Hewitt W, Armstrong ML. Tattooing and Body Piercing: Body Art Practices among College Students. Clin Nurs Res. 1999 Nov;8(4):368-85. Available from: https://pubmed.ncbi.nlm.nih.gov/10855104/

5. Mr. Basavaraj Mudhol AB. Knowledge Regarding Tattooing and Body Piercing Among the Users at Thamel-29, Kathmandu. Indian Journal Of Applied Research. 2014 Oct;4(10):383-5.

6. Tohme RA, Holmberg SD. Transmission of Hepatitis C Virus Infection Through Tattooing and Piercing: A Critical Review. Clinical Infectious Diseases. 2012 Apr 15;54(8):1167-78.

How to cite this article: Raju M, Elizabeth M, Thomas $\mathrm{M}$ et.al. Knowledge of adolescents regarding health implications of body piercing. Int J Health Sci Res. 2021; 11(12):16-20. DOI: https://doi.org/10.52403/ijhsr.20211203 